past, have for the most part paralleled the model for grieving. Hawkins (I99 I) and Doka (I995) both assert the uniqueness of each individual's dying and invite more openness to varied responses.

The model of grieving advanced by the author offers new challenges and creative approaches to those responsible for funeral arrangements and for religious groups. Our societies should offer greater freedom for grievers to choose rituals they value and to connect more effectively with others in sharing memories of the deceased. Even the computer might play a useful if impersonal role in hclping to create meaningful memories of the deceased. Lastly, the validation of other models of grieving could greatly modify our view of pathological responses. The assessment instruments now used to identify pathological grieving might need to be rewritten, and approaches to counsellors might need to revise their approach.

\title{
References
}

Doka, K. 1995. Coping with life-threatening illness: a task model. Omega 32, I I I-I 2 I. Hunasker Hawkins, A. I99I. Constructing death: three pathographies about dying. Omega, 22, 301-317.

Marshall, V. W. I986. A sociological perspective no aging and dying. In: V. W. Marshall (ed.), Later Life: The Social Psychology of Aging. Sage, London.

Stroebe, M. I 992 . Coping with bereavement: a review of the grief work hypothesis. Omega 26, 19-42.

Stroebe, W. and Schut, H. 1995. The Dual Process of Coping with Loss. Paper presented at the International Work Group on Death, Dying and Bereavement, Oxford.

Wortman, C. B. and Silver, R. G. 1989 . The myths of coping with loss. Fournal of Consulting and Clinical Psychology 57, 349-357.

Worden, J. W. 1983. Grief Counselling and Grief Therapy. Routledge, London. Second edition, I991.

\section{European Policy Issues}

\section{Tony Maltby}

J. Večerník. Incomes in central Europe: distributions, patterns and perceptions, Journal of European Social Policy, 6, 2 (I996), Iо I-1 22.

The first abstracted article offers comparative data on earnings and household incomes in what are sometimes referred to as the "Visegrad Four' countries (Hungary, Poland, Slovakia and the Czech Republic). All face similar problems in the provision of social welfare, but systematic and reliable comparative statistical information on earnings and household incomes among them is difficult to come by. This important article analyses recent trends since 1989 in the distribution of earnings and household incomes across and within the four countries. The paper draws from several sources, notably Social Stratification in 
Eastern Europe after I989, a study conducted by Treiman and Szelenyi at the University of California, Los Angeles in 1993, the Social Costs of Economic Transformation database gathered at the Institute for Human Sciences, Vienna, and the Luxembourg Income Study.

The paper presents a considerable amount of quantitative and qualitative data through numerous charts and tables. In providing this level of analysis, it plugs a gap in the literature and is to be welcomed. The article clearly demonstrates that, since 1989 , 'inequality rose in both personal and household incomes' (p. IOI) in these countries. Additionally, it suggests that differences between countries were 'maintained or even strengthened' (p. I 04), with earnings inequality being the highest in Hungary and relatively small in the Czech Republic. This will not surprise those who monitor social policy in central and eastern Europe. I would agree with Večerník when he indicates that, "social policy ought to challenge the huge amount of "new poverty" ... and the resulting polarization of societies' (p. I I9). The reality is however that the implementation of social policy in many if not all of the Visegrad countries is largely bounded by the economic and financial conditions imposed by the International Monetary Foundation and the World Bank. They have, for example, insisted upon reductions in social welfare expenditure in these countries as a condition for loans. As to the interests of social gerontology, the article does not provide detailed analysis of the position of older people in these countries, but despite this omission it is broadly informative and highly recommended.

A. Eylenbosch and K. Verreth. Equal treatment for men and women in complementary pensions: answers or unresolved questions? Journal of European Social Policy, 6, 2 (1996), I 23-I 46.

In the same journal issue as Večerník's article, this paper presents a review and appraisal of the effects on European law and European pensions' policy of the ambiguities raised by the landmark Barber judgement. This is achieved through analysis of six prominent cases recently taken to the European Court of Justice. The cases studies are Vroege, Fisscher, Van den Akker, Smith, Beune and Coloroll, and they will be of interest to those concerned with equal opportunities and pensions policy and more widely. The discussion first provides a detailed review of the socio-legal issues in this area. In particular, the direct effect and importance for pensions policy of Article I I9, the European Community Treaty and Directive 86/378/EEC, the Barber judgement and 
the Maastricht Protocol. It then considers how each of the six cases jointly and collectively have affected the Court's understanding of the issue of equal pay for equal work in complementary pension schemes. The authors note that although many of the problems and difficulties raised by Barber have been resolved, ambiguities remain, in particular, about which criteria can be used to determine the exact meaning of pay under Article I I 9. This was always going to be difficult to define in law. On the positive side, they suggest that the Court's decisions continue to maintain the principle of equal treatment for men and women. However, I share the opinion expressed in their final statement, that legal equality and societal equality do not always go hand-in-hand.

R. Deattie and W. McGillivray. A risk strategy: reflections on The World Bank report, Averting the Old Age Crisis, International Social Security Review, 48, 3-4, (1995), 5-22.

E. Reynaud. Financing retirement pensions: pay-as-you-go and funded systems in the European Union, International Social Security Review, 48, 3-4, (1995), 41-57.

The double thematic issue of the International Social Security Review from which these two articles are drawn contains several interesting articles on pension reform. Collectively they counter much of the analysis contained in the important and influential World Bank Report, Averting the Old Age Crisis: Policies to Protect and Promote Growth. Of particular note are the articles by Michel Voirin and Monika Queisser (of The World Bank). Voirin's article presents a comparative and cross-national review and an analysis of public and private pension schemes. Bearing in mind the conclusions advanced by the report, I recommend close attention to the Quessier article on pension reforms in Chile and Latin America, as also to a reflective and critical discussion document from the Suntory and Toyota International Centre for Economics and Related-Disciplines (Lloyd-Sherlock and Johnson i 996).

Beattie and McGillivray offer a critical assessment of The World Bank report. They argue that contrary to its view, the shortcomings of public sector pension systems also apply to private sector schemes. They also suggest that much of the evidence contained in the report is based upon a misrepresentation of the evidence. They suggest that moving away from social insurance to a mandatory savings scheme $(c . f$. Chile), as The Bank's report suggests, would involve an 'unacceptably high risk for workers and pensioners' (p. 5), and would increase the 
cost of pensions and impose an increasingly heavy burden on the current workforce. Although unsurprising, for the authors work for the International Labour Organisation and the International Social Security Association, this conclusion should be welcomed. Following their critical analysis of The World Bank's report, they temper their assessment by noting as most commentators have done, that the report contains 'a wealth of information and statistics on public and private pension schemes' and is a 'valuable contribution' to the debate on the future of pensions (p. 5).

Their conclusions suggest 'a way forward'. They argue that discussions of pension reform have too often been conflated with issues of privatisation and the wider role of government. They suggest that the 'application to social policy of principles applicable to general economic activity is not necessarily an illuminating one' (p. $2 \mathrm{I}$ ). They propose that the key to any discussion on pension reform should focus upon the quality of governance, 'which covers everything from the coherence of decision-making through good management and sound investment policies down to the efficient collection of contributions and timely payment of benefits' (p. 22).

The issue of financing pension schemes is also the focus of Reynaud's paper. It argues that, contrary to popular belief, the methods used to fund retirement pension schemes, usually distinguished as either pay-as you-go or insurance funded, are in fact much more diverse. The author provides a very clear and precise account of the two main methods to demonstrate this point, and offers examples from several European Union countries. She then suggests that in the national context, no one single model applies, but rather that there are a 'series of characteristics unique to each country' (p. 57): a point which The World Bank report chooses to ignore. It is increasingly argued that the so-called 'problem' of ageing populations is now global and not specifically European. One can agree but it remains the case that national solutions have to respect the specific cultural, historical and political traditions of their own social policy.

\section{Reference}

Lloyd-Sherlock, P. and Johnson, P. (eds) 1996 Ageing and Social Policy: Global Comparisons. Occasional Paper 19, Suntory-Toyota International Centre for Economics and Related Disciplines, London School of Economics, London.

Department of Social Policy and Social Work, University of Birmingham 